\title{
The Facilitation in the Structure of Cognitive Activity at the English Lessons at Secondary Schools
}

\section{Місце фасилітації у структурі пізнавальної діяльності на уроках англійської мови в закладах середньої освіти}

\author{
Nataliia Khupavtseva \\ Ph.D. in Psychology, Assistant Professor, Rivne State Univer- \\ sity of the Humanities, Rivne (Ukraine) \\ ORCID ID: https://orcid.org/0000-0002-8883-7686 \\ Researcher ID: AAC-2156-2019 \\ E-mail: natalahupavceva@gmail.com
}

\section{Наталія Хупавцева}

Кандидат психологічних наук, доцент, Рівненський державний гуманітарний університет, м. Рівне (Україна)

\section{ABSTRACT}

The purpose of our research is to analyze all components of cognitive activity in terms of their facilitative function, including, in some cases, English lessons.

Methods of the research. The following theoretical methods of the research were used to solve the tasks formulated in the article: a categorical method, structural and functional methods, the methods of the analysis, systematization, modeling, generalization.

The results of the research. It was justified that any activity contained in its structure some blocks interacting with each other: the first block - the block of needs, motives, interests; the second block - the operational one, which contains

Address for correspondence, e-mail: kpnu_lab_ps@ukr.net Copyright: (C) Khupavtseva Nataliia

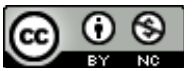

The article is licensed under CC BY-NC 4.0 International (https://creativecommons.org/licenses/by-nc/4.0/)

(C) Khupavtseva Nataliia

DOI (article): https://doi.org/10.32626/2227-6246.2020-48.293-312 
the system of operations, actions and their goals; the third block - the block of business and interpersonal communication related to any kind of cognitive activity at the English lessons.

It was proved that there was a pattern that made it possible to change interpersonal relationships in a group of students (updating the 1st block), and not to act directly from the point of view of these relationships, but to organize the cognitive activity of pupils (updating the 2nd block). Purposeful restructuring of these stages and goals of the activity (updating the 2nd block), due to the direct dependence on many external factors, will change the nature of the relationships in the group (updating the 1st block). In turn, the changes of interpersonal relationships (updating the $3 d$ block) facilitates changes in the 1st and the 2nd blocks, which will help to shape the needs, motives, interests of pupils. Based on this regularity, we can clearly outline the role of facilitation in the data of interacting blocks of cognitive activity. Facilitation involves changing the position of a methodologist, a teacher in the process of teaching. By updating at the level of all blocks, the teacher skillfully facilitates (manages, directs, assists) pupils in their learning activities. Therefore, there is a certain new formation, where the main figure is the schoolboy / schoolgirl as the subject of his / her own cognitive activity; a methodologist (a teacher) only uses all the opportunities of the educational environment, directs the student's activities in order to further development of his / her personality.

The following functions of facilitation are offered: the function of stimulation, the function of actualization, the function of forming the sovereignty of the pupils' personalities, managing the educational process, the function of interaction, the function of creative educational environment.

Conclusions. It was proved that all the exercises proposed by the author were facultative in their content. The facilitative context contains the tables offered by the teacher as samples and models at the beginning of each exercise. Pupils used to feel the facilitative relationships do not simply modify the educational environment, but radically transform it. Thus, the environment itself becomes a condition of their success in each situation. Interpersonal relationships of recognition of value, acceptance, trust created in the environment are the incentive for pupils to participation in their creative activities. These relationships, we believe, are largely effective in facilitating learning. First of all, expressiveness and "naturalness» are not the artificiality of the facilitator, the willingness to be a personality, to have and to feel the feelings and thoughts of a certain moment. When this "authenticity» includes attitudes of value, care, trust and respect for C Khupavtseva Nataliia

DOI (article): https://doi.org/10.32626/2227-6246.2020-48.293-312 
each pupil, the climate for the effective learning process can be created. When all these factors include sensory and empathetic listening to its content, then there is a climate of release that stimulates self-initiation of pupils who study.

Key words: facilitative interaction, cognitive activity, facilitative context, creative educational environment, needs, motives, interests, operational block, block of business and interpersonal communication.

\section{Вступ}

Фасилітація розглядається в психологічній літературі як специфічна діяльність, підпорядкована законам атрибутивного аналізу, запропонованого J. A. Fodor, M. Garrett i T. G. Bever (Fodor, Garrett \& Bever, 1968: 36-48). Такий аналіз створює певний алгоритм дій суб'єктів міжособистісної взаємодії, $з$ огляду на який кожне поняття відображає явище, а модель поняття, при цьому, відображає саме поняття. Модель поняття діяльності й модель явища не є одним і тим самим явищем. Поняття має відображати атрибути, компоненти, функції та структуру явища. Модель поняття може відображати, наприклад, лише атрибути явища та їх структуру, зазначають R. W. Gardner, D. N. Jackson i S. Messick (Gardner, Jackson \& Messick, 1960). Отже, поняття «фасилітація» відображає усвідомлену і цілеспрямовану діяльність як явище, властиве, в першу чергу, викладачеві. Тому можна виокремити атрибути фасилітації: 1) діяльність; 2) суб’єкт діяльності; 3) функції суб’єкта; 4) функції діяльності; 5) мотиви діяльності; 6) мета діяльності; 7) способи виконання діяльності; 8) предмет діяльності; 9) метод реалізації діяльності; 10) засоби, актуальні для реалізації діяльності; 11) результат діяльності (рис. 1).

Проте, стосовно фасилітативної взаємодії на уроках іноземної мови, то не всі питання є до кінця розв'язаними в психологічній літературі. Зокрема, слід проаналізувати всі виокремлені компоненти пізнавальної діяльності з точки зору їх фасилітативної функції, що й стало метою нашого дослідження.

(C) Khupavtseva Nataliia

DOI (article): https://doi.org/10.32626/2227-6246.2020-48.293-312 


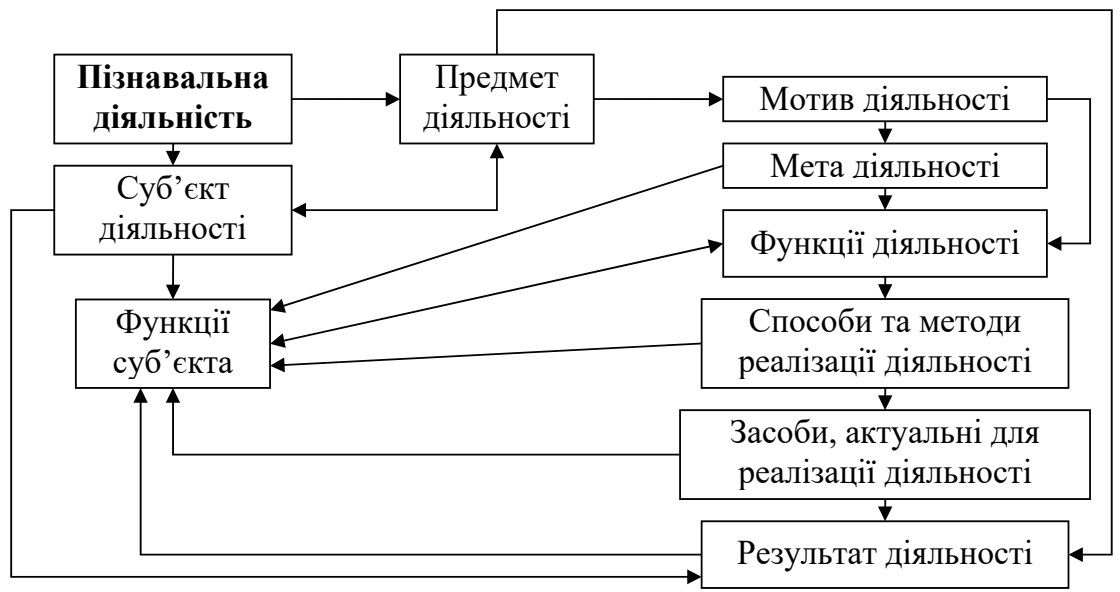

Puc. 1. Структура пізнавальної діяльності школярів у закладах середньої освіти

\section{Завдання статті}

1. Виокремити блоки пізнавальної діяльності.

2. Схарактеризувати прямі та зворотні зв'язки між компонентами блоків, зробити висновки щодо їх фасилітативного впливу на розвиток особистості учня.

3. Обгрунтувати місце фасилітації у структурі блоків пізнавальної діяльності.

4. Запропонувати функиї фасилітацї.

5. Розробити вправи для школярів на уроках іноземної (англійської) мови з урахуванням, по-перше, місця фасилітації у структурі блоків пізнавальної діяльності, по-друге, виокремлених нами функцій фасилітації.

\section{Методи дослідження}

Для розв'язання поставлених у роботі завдань використано такі теоретичні методи дослідження: категоріальний, структурно-функціональний, аналіз, систематизація, моделювання, узагальнення.

C) Khupavtseva Nataliia

DOI (article): https://doi.org/10.32626/2227-6246.2020-48.293-312 


\section{Результати та дискусії}

Розглянемо кожен із виокремлених компонентів, адже всі вони властиві для фасилітативної взаємодії. Загальновідомим є те, що діяльність - це основа, засіб і позитивна умова розвитку особистості. Діяльність - це доцільне перетворення людьми навколишньої дійсності. О. М. Леонтьєв називав діяльність одиницею життя, опосередкованою психічним відображенням (Леонтьев, 1983: 141). «Поза діяльністю не існує ні засобів діяльності, ні знаків, ні предметів мистецтва; поза діяльністю немає самих людей», - зазначає Г. П. Щедровицький (Щедровицкий, 1994: 35).

Отже, діяльність є цілеспрямованою, багатоступеневою активністю людини. «Цілеспрямована» - оскільки «предмет» постає її метою. «Багатоступенева» - оскільки включає в свою структуру дії, вторинну мотивацію, що визначаються метою та завданнями діяльності як такої. Це, своєю чергою, забезпечує актуалізацію особистістю основної мети-мотиву виконання діяльності. I, нарешті, операція діяльності відрізняється від дії тим, що вона позначається не метою, а умовами діяльності, у яких зазначена мета експлікується. Відрізняти дії від діяльності та від операцій вельми необхідно.

Процес фасилітації в навчальній діяльності не можна розуміти спрощено. Брати участь у діяльності та навчатися усвідомлено - це досить різні речі. Дія, якщо вона нав'язується командою методистів, учителів, педагогів тощо, здійснюється під тиском на учня, тоді вона сприймається без будь-якого сенсу, як так звана «тимчасова» необхідність.

У психології визнано такі атрибути особистості: їі свідомість і активність; атрибути психіки - суб'єктивність, активність, адаптивність; атрибути свідомості - переживання, знання і ставлення; атрибути діяльності - активність, усвідомлення, цілеспрямованість, умотивованість тощо.

Усі ці атрибути безпосередньо чи опосередковано включені до пізнавального процесу. Але в традиційній репродук-

(c) Khupavtseva Nataliia

DOI (article): https://doi.org/10.32626/2227-6246.2020-48.293-312 
DOI: https://doi.org/10.32626/2227-6246.2020-48

тивній системі навчання такі атрибути, як «свідомість», «активність», «суб’єктивність», «ставлення», «цілеспрямованість», «умотивованість», є ніби константними, незмінними компонентами. Психологи стверджують, що вони лише беруть участь у розгорнутій діяльності, що включає: планування, організацію, виконання, аналіз результатів, спілкування в референтній групі. Отже, суб'єкт навчання отримує доступ до усвідомлення сенсу пізнавальної діяльності. Тільки на цій основі у людини можуть формуватися змістові мотиви, ціннісні орієнтації i, в кінцевому рахунку, спрямованість особистості та взаємостосунки з іншими (Швалб, 2013: 20). Ця формула «фасилітативно доцільної діяльності» (терлін автора - H. Х.) відображає схему «відтворення нових знань» (Щедровицкий, 1994), апробовану нами у процесі пізнавальної діяльності, та застосовуватиметься з метою обгрунтування фасилітації як окремого виду діяльності.

Навчання на уроках у закладах середньої освіти має на увазі завдання організації спеціальної діяльності, з певною конкретною метою. Будь-яка діяльність містить у своїй структурі деякі блоки, що взаємодіють між собою (Максименко, 2005):

- I блок - блок потреб, мотивів, інтересів;

- II блок - операційно-дієвий, який уміщує систему операцій, дій та їх цілей;

вання, пов'язаний із діяльністю.

Прямі та зворотні зв'язки між компонентами блоків свідчать про те, що зміни в одному блоці призводять до змін в інших. Ці зміни можуть відбуватися як у конструктивному напрямку, так і в деструктивному, що, своєю чергою, призведе до розвитку або гальмування пізнавальної діяльності.

Отже, можна запропонувати закономірність, що уможливлює зміну міжособистісних взаємостосунків у групі школярів (актуалізація I блоку), для чого слід здійснювати ді(C) Khupavtseva Nataliia

DOI (article): https://doi.org/10.32626/2227-6246.2020-48.293-312 
яльність не безпосередньо з огляду на ці взаємостосунки, а на організацію пізнавальної діяльності учнів (актуалізація II блоку). Цілеспрямована перебудова етапів і цілей діяльності (актуалізація II блоку), в силу прямої залежності від багатьох зовнішніх чинників, змінить характер взаємостосунків у групі (актуалізація I блоку). Своєю чергою, зміна міжособистісних взаємостосунків (актуалізація III блоку) фасилітує зміни в I та II блоках, що сприятиме формуванню потреб, мотивів, інтересів школярів (рис. 2). Виходячи 3 наведеної закономірності, ми можемо безпомилково окреслити роль фасилітації у цих взаємодіючих між собою блоках пізнавальної діяльності. Фасилітація передбачає зміни позиції методиста, вчителя, педагога у процесі навчання. Актуалізуючись на рівні всіх блоків, учитель уміло фасилітує (управляє, спрямовує, допомагає) учням у їх навчальній діяльності. Отже, з'являється певне новоутворення, у якому головною фігурою є сам школяр як суб'єкт власної пізнавальної діяльності; методист (учитель) лише використовує всі можливості освітнього середовища, спрямовує діяльність учня з метою подальшого розвитку його особистості.

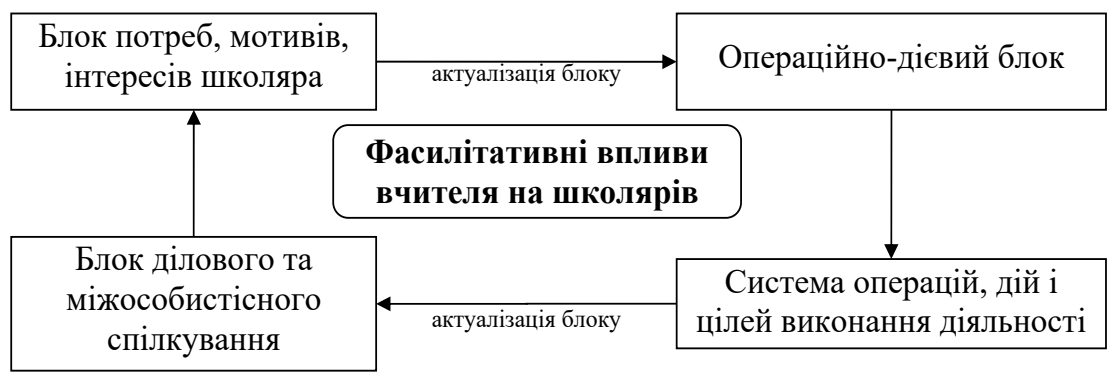

Puc. 2. Місце фасилітації у структурі блоків пізнавальної діяльності

Отже, фасилітація є специфічним видом діяльності вчителя. Ще у стародавній Греції говорили, що довший шлях у навчанні - через настановлення, а коротший - через при-

(C) Khupavtseva Nataliia

DOI (article): https://doi.org/10.32626/2227-6246.2020-48.293-312 
DOI: https://doi.org/10.32626/2227-6246.2020-48

клад. Саме цей «короткий шлях» у пізнанні й покликані показати вчителі-фасилітатори. У фасилітативній взаємодії суб’єктом діяльності може бути індивід (група, колектив), який чітко усвідомлює свої власні мотиви, цілі й способи виконання майбутньої пізнавальної діяльності та готовий за будь-яких умов її реалізувати.

Ми вважаємо, що функиіяли фасилітації є:

- функція стимулювання;

- функція актуалізації;

- функція формування суверенності особистості школяра;

- функція управління освітнім процесом;

- функція інтерактивної взаємодії;

- функція створення творчого освітнього середовища.

3 урахуванням рекомендацій Н. О. Михальчук (Михальчук, 2004: 171-179) щодо фасилітативного навчання, нами було розроблено вправи для школярів на уроках іноземної (англійської) мови. Ці вправи розроблено нами, по-перше, з урахуванням місця фасилітації у структурі блоків пізнавальної діяльності, по-друге, виокремлених нами функцій фасилітації. Так, темою уроку є «Weekend meals», урок проводиться в 5-му класі. Учитель пропонує учням текст:

"My dad works in a bank. He works there from Monday to Friday. He helps people. He counts money, and he uses the computer. His job is important. He is an important man at the bank.

Dad also works at home. On weekends he cooks dinner. Usually he fixes Italian food. On Saturdays he makes spaghetti. On Sundays he makes pizza. Sometimes he fries chicken or fixes Chinese food. My mother watches and helps. She cuts the vegetables. She tosses the salad. I wash the dishes.

Some people say it is strange for a man to cook. My dad enjoys his hobby. Cooking relaxes him. His father was a weekend cook, too».

(C) Khupavtseva Nataliia

DOI (article): https://doi.org/10.32626/2227-6246.2020-48.293-312 
DOI: https://doi.org/10.32626/2227-6246.2020-48 2020. випУСК 48

Exercise 1. Capital letters for nationalities and for the days of the week.

Names of nationalities begin with capital letters:
Italian
Chinese
Venezuelan American

The days of the week begin with capital letters, too.

$\begin{array}{llll}\text { Sunday } & \text { Monday } & \text { Tuesday } & \text { Wednesday } \\ \text { Thursday } & \text { Friday } & \text { Saturday } & \end{array}$

Copy the sentences, and make all the corrections that are necessary.

1. my father is a weekend cook

2. he works at a bank on monday, tuesday, wednesday, thursday, and friday

3. he cooks on saturday and sunday

4. usually he cooks Italian spaghetti

5. pizza is italian food

6. dad makes spaghetti on saturdays

7. my dad likes to cook chinese food

8. my mother and i help my dad

9. it is good for my dad to cook

10. his hobby relaxes him

Exercise 2. Grammar: Third person s forms. Spelling of present tense verbs.

Notice that verbs in the present tense take an ending with

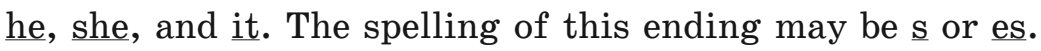
I help
we help
you help
you help
he helps
she helps
it help $\underline{s}$
they help

Almost all verbs add $\underline{\mathbf{s}}$ in the third person singular. Write the forms below with the correct spelling.

He works (work, know, count, make, use). She cuts (cut, help, cook, dance).

(C) Khupavtseva Nataliia

DOI (article): https://doi.org/10.32626/2227-6246.2020-48.293-312 
DOI: https://doi.org/10.32626/2227-6246.2020-48

2020. випУск 48

A few verbs add -es in the third person singular. They are verbs that end in $\underline{\mathbf{s}}, \underline{\mathbf{z}}, \underline{\mathrm{sh}}, \underline{\mathrm{ch}}$, or $\underline{\mathrm{x}}$. Write the forms below with the correct spelling.

He fixes (fix, finish, relax, rush).

She watches (watch, toss, wash, teach).

If a verb ends in a consonant and $-\mathrm{y}$, change the $\mathrm{y}$ to $\mathrm{i}$ before adding -es. If the verb ends in a vowel and $-\mathrm{y}$, simply add $\underline{\text { s; }}$ Write the forms below with the correct spelling.

He tries (try, fry, study, hurry, carry, marry).

She says (say, enjoy, play, stay, buy, pay).

The verb have is irregular. The third person singular form is has. He has a cookbook.

Exercise 3. Grammar: Subject-verb agreement.

Rewrite the sentences below, adding the correct form of the verb. Remember that he, she, and it take -s forms.

1. Most women cook the dinners at home. (cook)

2. My mother cooks most of the time. (cook)

3. She dinner on Mondays, Tuesdays, Wednesdays, and Thursdays. (make)

4. My father Italian food on the weekends. (fix)

5. My brother and I the dishes. (wash)

6. We the salad, too. (help with)

7. I to cook already. (know how)

8. Cooking my father. (relax)

9. Important people and all day. (rush, hurry)

10. Often they a hobby after work. (enjoy)

Exercise 4. Grammar: Object pronouns.

These are the forms of pronouns when they are the object of a verb or a preposition.

I / me you / your

we / us

he / him they / them you / your she / her it / its 
Rewrite each sentence and substitute an object pronoun for each noun. Follow the example.

a. My father helps people. My father helps them.

b. My father uses the computer.

c. My mother washes the vegetables.

d. I cut the vegetables.

e. My dad enjoys cooking.

f. He enjoys helping my mother.

g. Cooking relaxes my father.

h. My mother teaches my father to cook.

i. My dad teaches his son.

j. My mother helps my dad and me.

Exercise 5. Grammar: Sentence Construction Sentence patterns with verbs other than be.

You also have learned three sentence patterns with the verb to be:

Noun phrase + be + Noun phrase

Noun phrase + be + Adjective

Noun phrase + be + Adverb phrase

Other verbs can also be put in groups, according to the kinds of words that come after them. A verb that takes an object after it is a transitive verb (TV). Transitive verbs are in this pattern:

My father cooks dinner.

Noun phrase + Verb + Noun phrase (TV)

On the left there is a list of subjects. On the right there is a list of noun phrases that can be used as objects. Choose a subject and a verb and match them with the object to make a sentence. You may need to add - $\underline{\mathrm{s}}$ or -es to the verb.

Make as many sentences as you can.

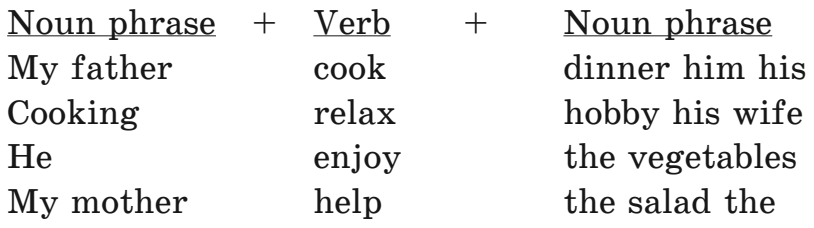

(C) Khupavtseva Nataliia 
DOI: https://doi.org/10.32626/2227-6246.2020-48

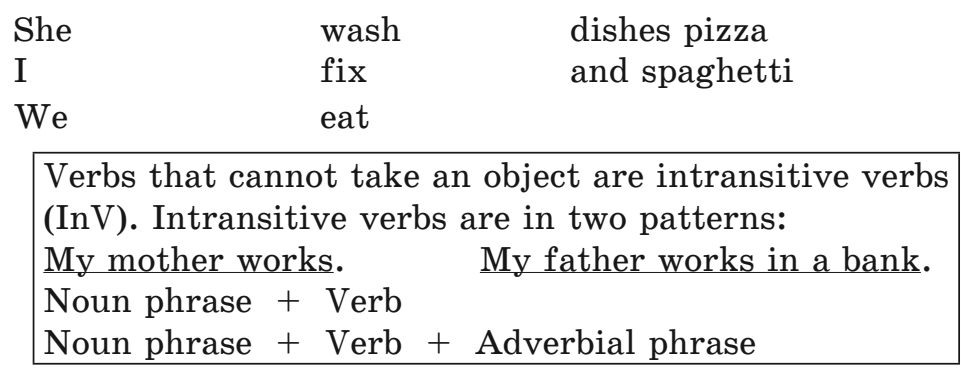

On the left there is a list of subjects. On the right there is a list of adverb phrases that can be used with intransitive verbs. Choose a subject and a verb and match them with an adverb phrase to make a sentence. You may need to add - $\underline{\mathbf{s}}$ or -es to the verb. Make as many sentences as you can.

$\begin{array}{lll}\begin{array}{l}\text { Noun phrase } \\ \text { My father }\end{array} & \begin{array}{l}\text { Verb } \\ \text { work }\end{array} & +\quad \begin{array}{l}\text { Noun phrase } \\ \text { very hard in }\end{array} \\ \text { He } & \text { cook } & \begin{array}{l}\text { a bank on the } \\ \text { weekend in the }\end{array} \\ \text { She } & \text { relax } & \begin{array}{l}\text { kitchen after } \\ \text { we }\end{array} \\ \text { I } & & \text { work together }\end{array}$

I

Exercise 6. Grammar: Adverbs of frequency with the be verb.

Adverbs of frequency tell how often something happens.

These words come after a form of the verb to be:

Father is never late.

Mother is usually busy.

Junior is always hungry.

Below there is a schedule that tells where each person in the family is during the week. Look at the schedule, and then write all the sentences with ad- verbs of frequency in the correct position. Use this scale as a guide:
7 days a week $=$ always;
5 or $6=$ usually;
$4=$ often;
2 or $3=$ sometimes;
$1=$ rarely;
and $0=$ never.

(C) Khupavtseva Nataliia

DOI (article): https://doi.org/10.32626/2227-6246.2020-48.293-312 
DOI: https://doi.org/10.32626/2227-6246.2020-48

2020. випуСК 48

\begin{tabular}{|c|c|c|c|c|c|c|c|}
\hline $\begin{array}{c}\text { The } \\
\text { person }\end{array}$ & $\begin{array}{c}\text { Sun- } \\
\text { day }\end{array}$ & $\begin{array}{c}\text { Mon- } \\
\text { day }\end{array}$ & $\begin{array}{c}\text { Tues- } \\
\text { day }\end{array}$ & $\begin{array}{c}\text { Wednes- } \\
\text { day }\end{array}$ & $\begin{array}{c}\text { Thurs- } \\
\text { day }\end{array}$ & $\begin{array}{c}\text { Fri- } \\
\text { day }\end{array}$ & $\begin{array}{c}\text { Satur- } \\
\text { day }\end{array}$ \\
\hline Dad & $\begin{array}{c}\text { at } \\
\text { home }\end{array}$ & $\begin{array}{c}\text { at the } \\
\text { bank }\end{array}$ & $\begin{array}{c}\text { at the } \\
\text { bank }\end{array}$ & $\begin{array}{c}\text { at the } \\
\text { bank }\end{array}$ & $\begin{array}{c}\text { at the } \\
\text { bank }\end{array}$ & $\begin{array}{c}\text { at the } \\
\text { bank }\end{array}$ & $\begin{array}{c}\text { at } \\
\text { home }\end{array}$ \\
\hline Mother & $\begin{array}{c}\text { at } \\
\text { home }\end{array}$ & $\begin{array}{c}\text { at } \\
\text { work }\end{array}$ & $\begin{array}{c}\text { at } \\
\text { home }\end{array}$ & $\begin{array}{c}\text { at } \\
\text { work }\end{array}$ & $\begin{array}{c}\text { at } \\
\text { home }\end{array}$ & $\begin{array}{c}\text { at } \\
\text { work }\end{array}$ & $\begin{array}{c}\text { at } \\
\text { home }\end{array}$ \\
\hline Junior & $\begin{array}{c}\text { at } \\
\text { home }\end{array}$ & $\begin{array}{c}\text { at } \\
\text { school }\end{array}$ & $\begin{array}{c}\text { at } \\
\text { school }\end{array}$ & $\begin{array}{c}\text { at } \\
\text { school }\end{array}$ & $\begin{array}{c}\text { at } \\
\text { school }\end{array}$ & $\begin{array}{c}\text { at } \\
\text { school }\end{array}$ & $\begin{array}{c}\text { at } \\
\text { home }\end{array}$ \\
\hline
\end{tabular}

1. Dad is at the bank.

2. Junior is at school.

3. Mother is

4. She is at home.

5. They are at work.

6. They are at home on the weekends.

Adverbs of frequency with other main verbs

The adverbs of frequency come before other main verbs besides to be.

Junior always helps at home.

Father sometimes cooks dinner.

Mother often works in the kitchen.

Look at the schedule below. It is a plan of the activity for a week for a family. Write all the sentences below with adverbs of frequency, telling how often each person works.

\begin{tabular}{|c|c|c|c|c|c|c|c|}
\hline The & un.- & Mon. & Tues.- & Wed & Thu & Fri.- & Sat.- \\
\hline ook & ad- & $\begin{array}{l}\text { Mot } \\
- \text {. }\end{array}$ & $\begin{array}{l}\text { Mot } \\
- \text {. }\end{array}$ & Moth & Mot & Moth & Dad-. \\
\hline les & Mother & & & & & Dad-. & \\
\hline & $\begin{array}{l}\text { Mother } \\
-.\end{array}$ & $\begin{array}{l}\text { Mother } \\
- \text {. }\end{array}$ & $\begin{array}{l}\text { Mother } \\
-.\end{array}$ & $\begin{array}{l}\text { Mother } \\
-.\end{array}$ & $\begin{array}{l}\text { Mot } \\
-.\end{array}$ & Dad-. & $\begin{array}{l}\text { Mother } \\
-.\end{array}$ \\
\hline $\begin{array}{l}\text { Nash the } \\
\text { lishes-. }\end{array}$ & $\begin{array}{l}\text { Junior } \\
-.\end{array}$ & $\begin{array}{l}\text { Junior } \\
-.\end{array}$ & $\begin{array}{l}\text { Junior } \\
-.\end{array}$ & $\begin{array}{l}\text { Junior } \\
-.\end{array}$ & $\begin{array}{l}\text { Junior } \\
- \text {. }\end{array}$ & $\begin{array}{l}\text { Junior } \\
-.\end{array}$ & \\
\hline
\end{tabular}

1. Junior washes the dishes.

2. Mother and Dad wash the dishes.

3. Mother tosses the salad.

4. Junior tosses the salad. 
DOI: https://doi.org/10.32626/2227-6246.2020-48 2020. ВИПУСК 48

5. Mother cooks dinner.

6. Dad cooks dinner.

7. Dad cuts vegetables.

8. Junior cuts vegetables.

9. Mother cuts vegetables.

10. These people work together.

Exercise 7. Grammar: Adverbs of time at the beginning of the sentence.

Sometimes adverbs of time can be at the beginning of a sentence. Rewrite these sentences and place the adverb or a phrase at the beginning.

1. Nobody is at home on Mondays. On Mondays nobody is at home.

2. Dad works at the bank from Monday to Friday.

3. Mom teaches at school on Mondays, Wednesdays, and Fridays.

4. Junior is usually at school.

5. Everybody is at home on weekends.

6. Dad often cooks spaghetti or pizza.

7. Mother sometimes goes out to work.

8. She usually rushes home to fix dinner.

9. Mother works very hard on Fridays.

10. Dad usually helps her with the salad on Fridays.

Exercise 8. Composition. Responding to questions.

Make a chart to show where the people in your family are every day.

\begin{tabular}{|l|l|l|l|l|l|l|l|}
\hline Name & Sunday & Monday & $\begin{array}{c}\text { Tues- } \\
\text { day }\end{array}$ & $\begin{array}{c}\text { Wednes- } \\
\text { day }\end{array}$ & $\begin{array}{c}\text { Thurs- } \\
\text { day }\end{array}$ & Friday & $\begin{array}{c}\text { Satur- } \\
\text { day }\end{array}$ \\
\hline & & & & & & & \\
\hline & & & & & & & \\
\hline & & & & & & & \\
\hline & & & & & & & \\
\hline
\end{tabular}

(C) Khupavtseva Nataliia

DOI (article): https://doi.org/10.32626/2227-6246.2020-48.293-312 
DOI: https://doi.org/10.32626/2227-6246.2020-48 2020. ВИПУСК 48

Find a partner in the class and discuss your chart with him / her. Ask him / her questions about his / her time chart, too. Then write a paragraph to answer these questions: Where is everyone on week days? Where is everyone on weekends? Where is usually your mother? Where is usually your father? Where are you?

\section{Exercise 8. Composition (test).}

Write a composition and tell who does some kinds of work in your family.

\section{Висновки}

Усі запропоновані нами вправи є фасилітативними за своїм змістом. Фасилітативний контекст уміщують підстановчі таблиці, пропоновані вчителем зразки та моделі на початку кожної вправи.

Учні, які звикли до фасилітативних відносин, є достатньою мірою сміливими, вони не просто модифікують освітнє середовище, а докорінно перетворюють його. Отже, саме середовище стає умовою їх ситуації успіху. Міжособистісні взаємостосунки визнання цінності, прийняття, довіри, створені в середовищі, є для учнів стимулом до участі у творчій діяльності. Ці взаємостосунки, ми вважаємо, є достатньо ефективними у сприянні навчанню. Перш за все, це експресивність і «натуральність», нештучність самого фасилітатора, готовність бути особистістю, бути і жити почуттями й думками певного моменту. Коли ця «справжність» включає в себе ціннісне ставлення, турботу, довіру і повагу до учня, клімат для ефективного процесу навчання можна вважати створеним. Коли ж це все включає до свого змісту чуттєве й емпатійне слухання, тоді дійсно існує клімат вивільнення, стимулюючий самоініціювання навчання і зростання.

\section{Література}

Гончарук Н., Онуфрієва Л. Психологічний аналіз рівнів побудови комунікативних дій. Psycholinguistics. Психолінгвістика. Психолинг-

(C) Khupavtseva Nataliia

DOI (article): https://doi.org/10.32626/2227-6246.2020-48.293-312 
вистика. 2018. Вип. 24 (1). С. 97-117. DOI 10.31470/2309-17972018-24-1-97-117.

Леонтьев А. Н. Избранные психологические произведения: в 2-х т. / под ред. В. В. Давыдова. Москва : Педагогика, 1983. Т. 2. 318 с.

Максименко С. Д. Розвиток особистості - розгортання чи новоутворення? Від самопізнання - до своєї професії. Шкільний світ. Психолог. Київ, 2005. № 1. С. 15-18.

Михальчук Н. О. Комунікативний метод навчання іноземних мов у контексті трансформації вищої освіти в простір кроскультурного спілкування. Філологічні студї. Науковий часопис. Луцьк, 2004. № 4. С. 171-179.

Швалб Ю. М. Методология и теория экспертной деятельности: психологические аспекты. Киев : Основа, 2013. 240 с.

Щедровицкий Г. П. Избранные труды. Москва : Издательство «Школы культурнойполитики», 1994. URL:https://gtmarket.ru/laboratory/ basis/3961.

Fodor, J. A., Garrett, M., \& Bever, T. G. (1968). Some syntactic determinants of sentential complexity. Perception and Psychophysics, (pp. 36-48). Oxford : Oxford University Press.

Gardner, R. W., Jackson, D. N., \& Messick, S. (1960). Personality organization in cognitive controls and intellectual abilities. Psychological, $2,8,148$.

\section{References}

Honcharuck, N., \& Onufriieva, L. (2018). Psykholohichnyi analiz rivniv pobudovy komunikatyvnykh dii [Psychological analysis of levels of communicative actions' constructing]. Psycholinguistics. Psykholinhvistyka. Psikholingvistika - Psycholinguistics, 24 (1), 97-117. DOI 10.31470/2309-1797-2018-24-1-97-117 [in Ukrainian].

Leontiev, A. N. (1983). Izbrannyie psikhologicheskiie proizvedeniia [Selected Psychological Articles]. V. V. Davydov (Ed.). (Vol. 2). Moskva : Pedagogika [in Russian].

Maksymenko, S. D. (2005). Rozvytok osobystosti - rozhortannia chy novoutvorennia? Vid samopiznannia - do svoiei profesii [Person's development - deployment or new formation? From self-cognition - to his / her profession]. Shkilnyi svit. Psykholoh - The school world. Psychologist, 1, 15-18. Kyiv [in Ukrainian].

Mykhalchuk, N. O. (2004). Komunikatyvnyi metod navchannia inozemnykh mov u konteksti transformatsii vyshchoi osvity v prostir kroskulturnoho spilkuvannia [Communicative method of teaching foreign languages in the context of transformation of higher education into (C) Khupavtseva Nataliia

DOI (article): https://doi.org/10.32626/2227-6246.2020-48.293-312 
a cross-cultural communication]. Filolohichni studii. Naukovyi chasopys - Philological studios. Scientific journal, 4, 171-179. Lutsk [in Ukrainian].

Shvalb, Yu. M. (2013). Metodologiia i teoriia ekspertnoi deiatelnosti: psikhologicheskie aspekty [Methodology and theory of expert's activity: psychological aspects]. Kiev : Osnova [in Russian].

Shchedrovitskii, G. P. (1994). Izbrannyie trudy [Selected Articles]. Moskva : Izdatelstvo «Shkoly kulturnoi politiki». Retrieved from https:// gtmarket.ru/laboratory/basis/3961 [in Russian].

Fodor, J. A., Garrett, M., \& Bever, T. G. (1968). Some syntactic determinants of sentential complexity. Perception and Psychophysics, (pp. 36-48). Oxford : Oxford University Press.

Gardner, R. W., Jackson, D. N., \& Messick, S. (1960). Personality organization in cognitive controls and intellectual abilities. Psychological Issues, 2, 8, 148.

Хупавцева Наталія. Місце фасилітації у структурі пізнавальної діяльності на уроках англійської мови в закладах середньої освіти

\section{АНОТАЦІЯ}

Мета нашого дослідження - проаналізувати всі компоненти пізнавальної діяльності з точки зору їх фасилітативної функції, дотично, зокрема, до уроків англійської мови.

Для розв'язання поставлених у роботі завдань використано такі теоретичні методи дослідження: категоріальний, структурно-функціональний, аналіз, систематизація, моделювання, узагальнення.

Результати дослідження. Обгрунтовано, що будь-яка діяльність містить у своїй структурі деякі блоки, що взаємодіють між собою: І блок - блок потреб, мотивів, інтересів; I/ блок-операційно-дієвий, який умішує систему операцій, дій та їх цілей; III блок - блок ділового та міжособистісного спілкування, пов'язаний із діяльністю.

Доведено, що існує закономірність, що уможливлює зміну міжособистісних взаємостосунків у групі школярів (актуалізація I блоку), для чого слід здійснювати діяльність не безпосередньо з огляду на ці взаємостосунки, а на організацію пізнавальної діяльності учнів (актуалізація II блоку). Цілеспрямована перебудова етапів і цілей діяльності (актуалізація I/ блоку), в силу прямої залежності від багатьох зовнішніх чинників, змінить характер взаємостосунків у групі (актуалізація I блоку). Своєю чергою, зміна міжособистісних взаємостосунків (актуалізація III блоку) фра-

(c) Khupavtseva Nataliia

DOI (article): https://doi.org/10.32626/2227-6246.2020-48.293-312 
силітує зміни в I та II блоках, що сприятиме формуванню потреб, мотивів, інтересів школярів. Виходячи з наведеної закономірності, ми можемо безпомилково окреслити роль фасилітації у цих взаємодіючих між собою блоках пізнавальної діяльності. Фасилітація передбачає зміни позиції методиста, вчителя, педагога у процесі навчання. Актуалізуючись на рівні всіх блоків, учитель уміло фрасилітує (управляє, спрямовує, допомагає) учням у їх навчальній діяльності. Отже, з'являється певне новоутворення, у якому головною фігурою є сам школяр як суб'єкт власної пізнавальної діяльності; методист (учитель) лише використовує всі можливості освітнього середовища, спрямовує діяльність учня з метою подальшого розвитку його особистості.

Запропоновано функції фрасилітації, такі як: функція стимулювання; функція актуалізації; функція формування суверенності особистості школяра; функція управління освітнім процесом; функція інтерактивної взаємодії; функція створення творчого освітнього середовища.

Висновок. Доведено, що всі запропоновані авторкою статті вправи $\epsilon$ фасилітативними за своїм змістом. Фасилітативний контекст уміщують підстановчі таблиці, пропоновані вчителем зразки та моделі на початку кожної вправи. Учні, які звикли до фасилітативних відносин, $\epsilon$ достатньою мірою сміливими, вони не просто модирікують освітнє середовище, а докорінно перетворюють його. Отже, саме середовище стає умовою їх ситуації успіху. Міжособистісні взаємостосунки визнання цінності, прийняття, довіри, створені в середовищі, $є$ для учнів стимулом до участі у творчій діяльності. Ці взаємостосунки, ми вважаємо, $\epsilon$ достатньо ефективними у сприянні навчанню. Перш за все, це експресивність і «натуральність», нештучність самого фасилітатора, готовність бути особистістю, бути і жити почуттями і думками певного моменту. Коли ия "справжність» включає в себе ціннісне ставлення, турботу, довіру і повагу до учня, клімат для ерективного прочесу навчання можна вважати створеним. Коли ж це все включає до свого змісту чуттєве й емпатійне слухання, тоді дійсно існує клімат вивільнення, стимулюючий самоініціювання навчання і зростання.

Ключові слова: фасилітативна взаємодія, пізнавальна діяльність, фасилітативний контекст, творче освітне середовище, потреби, мотиви, інтереси, операційно-дієвий блок, блок ділового та міжособистісного спілкування.

(C) Khupavtseva Nataliia

DOI (article): https://doi.org/10.32626/2227-6246.2020-48.293-312 
DOI: https://doi.org/10.32626/2227-6246.2020-48

2020. випуск 48

Хупавцева Наталия. Место фасилитации в структуре познавательной деятельности на уроках английского языка в учреждениях среднего образования

\section{АННОТАЦИЯ}

Цель нашего исследования - проанализировать все компоненты познавательной деятельности с точки зрения их фасилитативной функции, касательно, в частности, уроков английского языка.

Для решения поставленных в работе задач использованы следующие теоретические методы исследования: категориальный, структурно-функкциональный анализ, методы систематизации, моделирования, обобщения.

Результаты исследования. Обосновано, что любая деятельность включает в свою структуру отдельные блоки, которые взаимодействуют между собой: I блок - блок потребностей, мотивов, интересов; II блок - операционально-действенный, содержащий систему операций, действий и их целей; III блок - блок делового и межличностного общения, связанный непосредственно с деятельностью.

Доказано, что существует закономерность, учитывая которую возможно изменить межличностные взаимоотношения в группе школьников (актуализация I блока), для чего следует осуществлять деятельность не непосредственно учитывая эти взаимоотношения, а с учетом правил организации познавательной деятельности учащихся (актуализация (I блока). Целенаправленная перестройка этапов и целей деятельности (актуализация II блока), в силу своей прямой зависимости от многих внешних факторов, способна изменить характер взаимоотношений в группе (актуализация II блока). В свою очередь, изменение межличностных взаимоотношений (актуализация III блока) фасилитирует изменения в I и I/ блоках, что будет способствовать формированию потребностей, мотивов, интересов школьников. Исходя из данной закономерности, мы можем безошибочно определить роль фасилитации в парадигме взаимодействующих между собой блоков познавательной деятельности. Фасилитация предусматривает изменение позиции методиста, учителя, педагога в прочессе обучения. Актуализируясь на уровне всех блоков, учитель умело фасилитирует (управляет, направляет, помогает) ученикам в их учебной деятельности. Таким образом, появляется определенное новообразование, в структуре которого главной фи-

(C) Khupavtseva Nataliia

DOI (article): https://doi.org/10.32626/2227-6246.2020-48.293-312 
гурой является сам школьник как субъект собственной познавательной деятельности; методист (учитель) только использует все возможности образовательной среды, направляет деятельность ученика с целью дальнейшего развития его личности.

Предложены функции фрасилитации: функция стимулирования; функция актуализации; функция формирования суверенности личности школьника; функция управления образовательным процессом; функция интерактивного взаимодействия; функция создания творческой образовательной среды.

Вывод. Доказано, что все предложенные автором статьи упражнения являются фасилитативными по своему содержанию. Фасилитативный контекст содержат таблицы, предлагаемые учителем образцы и модели в начале каждого упражнения. Ученики, которые привыкли к фасилитативным отношениям, являются в достаточной степени смелыми, они не просто модифицируют образовательную среду, а коренным образом преобразуют ее. Таким образом, сама среда становится условием их ситуации успеха. Межличностные взаимоотношения признания ценности, принятия, доверия, созданные в среде, являются для учащихся стимулом к участию в творческой деятельности. Эти взаимоотношения, мы считаем, во многом являются эффективными в содействии обучению. Прежде всего, это экспрессивность и "натуральность», неискусственность самого фасилитатора, готовность быть личностью, быть и жить чувствами и мыслями определенного момента. Когда эта «подлинность» включает в себя ценностное отношение, заботу, доверие и уважение к ученику, климат для эфрективного процесса обучения можно считать созданным. Когда же это все включает в свое содержание чувственное и эмпатийное слушание, тогда действительно существует парадигма освобождения, стимулирующая самоинициирование обучения и личностного роста.

Ключевые слова: фасилитативное взаимодействие, познавательная деятельность, фасилитативный контекст, творческая образовательная среда, потребности, мотивы, интересы, операционно-действенный блок, блок делового и межличностного общения.

Original manuscript received January 29, 2020 Revised manuscript accepted February 22, 2020

(C) Khupavtseva Nataliia

DOI (article): https://doi.org/10.32626/2227-6246.2020-48.293-312 